\title{
Process-cost analysis of productivity and wages in agro-industrial processing organizations
}

\author{
Oksana Pirogova ${ }^{1}$, Roman Nuzhdin ${ }^{2}$, Nadezhda Kondrashova ${ }^{3}$, and Oksana Lukina ${ }^{2}$ \\ ${ }^{1}$ Peter the Great St. Petersburg Polytechnic University, Institute of Industrial Management, \\ Economics and Trade, Graduate School of Service and Trade, 29 Polytechnicheskaya str., St. \\ Petersburg, Russia, 195251 \\ ${ }^{2}$ Voronezh State University of Engineering Technologies, Department of the Theory of Economics \\ and Accounting Policy, 19 Revolyucii. Avenue, Voronezh, Russia, 394000 \\ ${ }^{3}$ Voronezh State University, Department of the Economic Analysis and Audit, Universitetskaya \\ ploshchad', Voronezh, Russia, 394018
}

\begin{abstract}
Process-cost analysis involves the implementation of appraisal procedures at each stage of adding value, which is considered as the main source of achieving the interests of personnel, owners and the state. The main goal of this study is to verify the existing methodological approaches to assessing the labor productivity of personnel in processing organizations of the agro-industrial complex, to assess the dynamic ratio of productivity and wages, based on methodologically justified assessment procedures that ensure the implementation of the advantages of process-cost analysis and eliminate the disadvantages of traditional methods. In order to improve the analytical suitability of the results of the process-cost analysis of labor results, three areas of key stakeholders' interest are identified, for each of which corrective operations are provided that provide not only the possibility of a retrospective analysis, but also predicting the possibility of parity of interests. Based on the results obtained, it was concluded that the share of value added in total revenues is low, the level of wages is unreasonable and, consequently, significant disparities in the distribution of value added. The inconsistency of the criterial assessment of the dynamic ratio of labor productivity and its payment in modern conditions has been proved.
\end{abstract}

\section{Introduction}

The development of the economy in general and the processing organizations of the agroindustrial complex, in particular, is associated with the need to increase labor productivity. This position is not in doubt and is confirmed in many domestic and foreign studies carried out at the macro and micro levels with an emphasis on various essential characteristics of this aspect, including the factors that determine its level and dynamics [1]. At the same time, our content analysis allowed us to identify certain positional disagreements, which are

\footnotetext{
*Corresponding author: kafedra17@rambler.ru
} 
due to the postulation of the requirement for outstripping growth of labor productivity in comparison with wages [2]. As a rule, the principle support of this ratio is expressed under the assumption that the amount of remuneration is at a sufficient level to ensure the necessary motivation of personnel for highly productive work and the development of the labor component.

Considering labor productivity as a synthetic resulting parameter of the development of economic entities and having ascending opportunities for managerial influences and reducing the cost and time of their implementation, without begging the resulting significance of each, three main aspects can be distinguished that determine the level of productivity of the organization as a whole as a system. First, when assessing the productivity of agro-industrial complex processing organizations per unit of time, the limiting factor is the production capacity, which determines the maximum possible volume of finished goods production. Secondly, the organization of production processes is important when comparing two enterprises with a comparable level of production capacity and using the same technologies. The suboptimal organization of production and the effectiveness of supporting processes leads to underutilization of production capacity. Thirdly, the level of qualifications of personnel must correspond to the level of equipment and technologies used in production activities. Labor productivity of personnel in physical terms (output) is calculated as the ratio of the volume of products produced to the number of personnel, or labor costs (time). For the purposes of assessing the vector of the dynamic ratio, both options are acceptable, since both the volume of production and wages in both cases are taken for the same period of time, which ensures the unity of the results obtained. In our opinion, the objectivity of this approach does not raise doubts and any difficulties in performing assessment procedures and interpreting the results obtained.

A certain discrepancy at the methodological level, requiring additional clarification and elimination, arises when using cost indicators in the process of assessing both productivity and wages in space and time [3]. As the cost results of labor received by one employee or per unit of time, when calculating productivity, the following are traditionally used: revenue (income minus VAT) [3], profit (gross, from sales, net) [3] or value added [3]. A common disadvantage of the cost approach is the use of the implementation results of the reporting (current) period, and not production. In this case, the results of production, including past periods, are taken into account, but the balances of finished goods produced in the current period are not considered. It should be noted that the discrepancy between the period of production and sales of products requires certain methodological adjustments when calculating indicators, the information base for which is the "Report on financial results" and information on production costs (production results). We believe that the absolute indicators of the Statement of Financial Results should be adjusted taking into account the structure of shipped products (the share of last year's residues and the share of products in the reporting period). Ignoring this condition can lead to incorrect assessment results and the development of incorrect management decisions as a result.

The use of proceeds, despite the simplicity of calculations and recommendations of individual authors, is the most incorrect from an economic point of view. First, revenue is structurally the result of the labor of personnel not only of the manufacturing organization, but also of the supplier organizations, expressed in the cost of raw materials, materials, works and services. In material-intensive industries, which include the production of beet sugar, the share of purchased resources in the production cost may exceed $80 \%$. Secondly, revenue characterizes the result of only the main (ordinary) activities. Underreporting income from other activities when assessing labor productivity throughout the organization can have a significant impact on the level of the results obtained and their analytical suitability. 
The use of the profit indicator in calculating labor productivity should also be recognized as incorrect for many reasons, including the receipt of negative financial results.

The most reasonable, in our opinion, is the calculation of labor productivity based on the value added indicator. This approach has been used in many scientific practical works [4]. In international practice, gross value added (GVA) and net value added (NVA) are distinguished. When calculating NVA, total revenues are reduced by the amount of accrued depreciation; when calculating GVA, such an adjustment is not made.

Order of the Ministry of Economic Development of Russia dated December 28, 2018 No. 748 approved the Methodology for calculating labor productivity indicators of enterprises, industry and constituent entities of the Russian Federation. In accordance with this methodology, for organizations that do not prepare consolidated financial statements in accordance with the requirements of international financial reporting standards, value added is defined as "the sum of profit, labor costs, insurance payments, taxes and fees (excluding income tax) and depreciation fixed assets and intangible assets ". A similar approach to calculating value added (GVA) at the state level is used in determining GDP. However, its application on the scale of an economic entity in determining labor productivity, in our opinion, is highly controversial. First, depreciation charges represent a part of the initial cost of objects written off in a given period to the cost of production (that is, they are the organization's payment for the use of fixed assets and intangible assets). The cost of the acquired objects (in full) should be taken into account only by the organizations that produced them; otherwise, the previously created added value is re-recorded. Even if the objects were created by the organization on its own, then the costs of labor, insurance payments, taxes and fees were taken into account as part of the added value in the periods in which they were created. Secondly, if an organization does not buy a fixed asset and, as a result, does not charge depreciation (in the amount of 100,000 rubles), but rents an object (for 100,000 rubles), then, in accordance with the recommended methodology, the added value and productivity, all other things being equal, in this case will be lower. From the point of view of assessing labor productivity, the way non-current assets enter the organization is not fundamental and does not have a different-sized effect on labor results.

In these conditions, the importance of methodological aspects that determine the content and procedure for the implementation of assessment procedures, and the need for their development and adaptation to specific management tasks, primarily at the level of economic entities, increases.

\section{Materials and methods}

To neutralize the influence of the time factor in calculating the mass of value added for the purpose of assessing labor productivity, we propose the following algorithm [5]:

1) establish a balance of production of finished products, determine the share of finished products of the reporting and previous periods in the sales volume of the reporting period;

2) determine the amount of income for the main and other types of activities for the reporting period (according to the "Statement of financial results");

3) determine the amount of material costs attributable to products sold in the reporting period;

4) determine the amount of depreciation charges attributable to products sold in the reporting period;

5) deduct from the total income of the reporting period (cl.1):

- the total amount of other expenses (according to the "Statement of financial results");

- the adjusted amount of material costs (cl.3);

- the adjusted amount of depreciation deductions (cl.4). 
Analytical calculations in accordance with the proposed algorithm were performed according to data from eight sugar production organizations in the Voronezh region for 2014-2018 (tables 1-2). All selected organizations are part of the Prodimex group of companies, which ensures the unity of the accounting and analytical tools used and the comparability of data.

Table 1. Balance of finished and shipped products in organizations $\mathrm{C} 1-\mathrm{C} 8$ of the Voronezh region (2014 - 2018) abor component.

\begin{tabular}{|c|c|c|c|c|c|c|}
\hline Organization & Year & $\begin{array}{c}\text { Balance of } \\
\text { finished products } \\
\text { at the beginning } \\
\text { of the year, } t\end{array}$ & $\begin{array}{c}\text { Finished goods } \\
\text { produced, } \mathrm{t}\end{array}$ & $\begin{array}{l}\text { Finished } \\
\text { products } \\
\text { shipped, } t\end{array}$ & $\begin{array}{c}\text { Balance of } \\
\text { finished } \\
\text { products at the } \\
\text { end of the year, } \\
t\end{array}$ & $\begin{array}{c}\text { Share of } \\
\text { manufactured and } \\
\text { sold products in } \\
\text { the reporting } \\
\text { year, } \%\end{array}$ \\
\hline \multirow{5}{*}{$\mathrm{C} 1$} & 2014 & 0 & 122411 & 67379 & 55032 & 55,04 \\
\hline & 2015 & 55032 & 148493 & 113287 & 90238 & 39,23 \\
\hline & 2016 & 90238 & 162387 & 122406 & 130219 & 19,81 \\
\hline & 2017 & 130219 & 165874 & 183311 & 112782 & 32,01 \\
\hline & 2018 & 112782 & 178083 & 165611 & 125254 & 29,67 \\
\hline \multirow{5}{*}{$\mathrm{C} 2$} & 2014 & 3660 & 44688 & 21435 & 26913 & 39,78 \\
\hline & 2015 & 26913 & 53682 & 48015 & 32580 & 39,31 \\
\hline & 2016 & 32580 & 63830 & 59081 & 37329 & 41,52 \\
\hline & 2017 & 37329 & 72508 & 74307 & 35530 & 51,00 \\
\hline & 2018 & 35530 & 45873 & 54702 & 26700 & 41,80 \\
\hline \multirow{5}{*}{$\mathrm{C} 3$} & 2014 & 0 & 64167 & 37862 & 26305 & 59,01 \\
\hline & 2015 & 26305 & 57827 & 47629 & 36503 & 36,88 \\
\hline & 2016 & 36503 & 88159 & 61135 & 63527 & 27,94 \\
\hline & 2017 & 63527 & 95579 & 100478 & 58628 & 38,66 \\
\hline & 2018 & 58628 & 93671 & 69587 & 82712 & 11,70 \\
\hline \multirow{5}{*}{$\mathrm{C} 4$} & 2014 & 8682 & 124123 & 91299 & 41506 & 66,56 \\
\hline & 2015 & 41506 & 157846 & 124787 & 74565 & 52,76 \\
\hline & 2016 & 74565 & 190624 & 168763 & 96426 & 49,42 \\
\hline & 2017 & 96426 & 206566 & 221602 & 81389 & 60,60 \\
\hline & 2018 & 81389 & 193303 & 192498 & 82195 & 57,48 \\
\hline \multirow{5}{*}{$\mathrm{C} 5$} & 2014 & 27713 & 52406 & 45290 & 34829 & 33,54 \\
\hline & 2015 & 34829 & 52123 & 46019 & 40933 & 21,47 \\
\hline & 2016 & 40933 & 53532 & 49450 & 45015 & 15,91 \\
\hline & 2017 & 45015 & 74704 & 59688 & 60031 & 19,64 \\
\hline & 2018 & 60031 & 90163 & 52114 & 98080 & $-8,78$ \\
\hline \multirow{5}{*}{ C6 } & 2014 & 0 & 18742 & 6440 & 12302 & 34,36 \\
\hline & 2015 & 12302 & 27008 & 25525 & 13785 & 48,96 \\
\hline & 2016 & 13785 & 31081 & 30065 & 14801 & 52,38 \\
\hline & 2017 & 14801 & 32476 & 32970 & 14307 & 55,95 \\
\hline & 2018 & 14307 & 23729 & 21407 & 16629 & 29,92 \\
\hline \multirow{5}{*}{$\mathrm{C} 7$} & 2014 & 0 & 45132 & 37509 & 7623 & 83,11 \\
\hline & 2015 & 7623 & 49776 & 27716 & 29683 & 40,37 \\
\hline & 2016 & 29683 & 58332 & 58039 & 29976 & 48,61 \\
\hline & 2017 & 29976 & 72948 & 66151 & 36773 & 49,59 \\
\hline & 2018 & 36773 & 78486 & 46127 & 69132 & 11,92 \\
\hline \multirow{5}{*}{$\mathrm{C} 8$} & 2014 & 0 & 40927 & 30562 & 10365 & 74,67 \\
\hline & 2015 & 10365 & 49697 & 34959 & 25103 & 49,49 \\
\hline & 2016 & 25103 & 49672 & 48760 & 26015 & 47,63 \\
\hline & 2017 & 26015 & 54657 & 35649 & 45023 & 17,63 \\
\hline & 2018 & 45023 & 41930 & 24367 & 62587 & $-49,26$ \\
\hline \multirow{5}{*}{$\begin{array}{l}\text { By group of } \\
\text { organizations }\end{array}$} & 2014 & 40055 & 448429 & 299914 & 188570 & 57,95 \\
\hline & 2015 & 188570 & 538625 & 420308 & 306887 & 43,02 \\
\hline & 2016 & 306887 & 609458 & 536564 & 379781 & 37,69 \\
\hline & 2017 & 379781 & 679733 & 673679 & 385835 & 43,24 \\
\hline & 2018 & 385835 & 651567 & 556826 & 480576 & 26,24 \\
\hline
\end{tabular}


The data in Table 1 indicate a co-directional (for each organization in most cases), but different-sized impact (for the compared organizations) of the factors of the external, coupled and internal environment on the results of economic activities of organizations C1C8. A tendency towards an increase in the balances of finished goods at the end of the year is characteristic of all surveyed organizations (Table 1). On the one hand, this is due to the specifics of seasonal production, an increase in production volume, on the other, creative decisions of the Management Company (Prodimex-Sugar Management Company), aimed, among other things, at ensuring the highest sales volume while setting maximum wholesale selling prices for sugar. For example, at the end of 2018 , only $11.92 \%$ of the finished products produced in the reporting period were sold for the group of organizations as a whole. Interesting, in our opinion, are the negative structural ratios obtained in 2018 by organizations $\mathrm{C} 5$ and $\mathrm{C} 8$, which indicate that these organizations during the year were unable to sell fully the remnants of finished products of previous years.

The data in Table 2 for the purposes of assessing labor productivity are intermediate, but already at this stage, they allow us to conclude that the results from other activities are significant and the need to consider them to achieve the set goals.

Since the ratio of labor productivity growth and its payment affects the interests of various stakeholders, there is a need to apply analytical procedures that assess value added, as well as to assess the possibilities of positive changes in the level of its structural elements and ensure a positive vector of their dynamics (parametric analysis).

The solution to this management problem provides the use of tools for process-value business analysis. Methodological support of business analysis of economic activity development of agro-industrial complex processing organizations, including sugar production, focused on the processes of adding business value, includes an assessment of indicators, indicators and parameters that take into account the interests of the state, organizations and personnel. In other words, adding value to a business not only increases its synergistic efficiency [6], but can also increase the tax burden on VAT. Therefore, taking the deductive approach as the basis of the process-cost business analysis, it is advisable to identify the causes and consequences of the formation of the added value mass and its change in the course of the development of the organization economic activity, not only as an economic entity that increases the value of the business, but also as a taxpayer burdened with obligations before the state, and the employer who motivates staff.

The cost of sales of products (works, services, etc.) can be aggregately represented as a set of: the cost of consumed material resources, value added (including profit), and value added tax (Figure 1).

The acquisition of material resources, as a rule, is associated with the payment of "input VAT", and their consumption - with the write-off of the amount of "input VAT". Thus, the cost of purchased raw materials and materials, fixed assets, works and services does not increase the amount of benefit created by the organization. At the same time, the presence of a certain type of resources (even if they are not used in business processes) is associated with the obligation of the organization to calculate and pay: property tax, land tax, tax, transport tax, the amounts of which increase the costs of organizations and, as a result, benefit.

The valuation of the use of human resources is characterized by the accrued income of the personnel, the sum of compulsory insurance premiums and premiums for insurance against industrial accidents and occupational diseases. In addition, considering the system of relations between the state, organization and hired personnel, one can make an educated assumption that the employer is interested in high-quality labor results, and the personnel in their adequate payment [7]. 
Table 2. Indicators determining the level of added value, organizations C1 - C8 of the Voronezh region (2014 - 2018).

\begin{tabular}{|c|c|c|c|c|c|c|}
\hline Organization & Year & $\begin{array}{l}\text { Total income, } \\
\text { thousand rubles }\end{array}$ & $\begin{array}{l}\text { Material costs, } \\
\text { thousand rubles }\end{array}$ & $\begin{array}{c}\text { Depreciation, } \\
\text { thousand rubles }\end{array}$ & $\begin{array}{l}\text { Other expenses, } \\
\text { thousand rubles }\end{array}$ & $\begin{array}{l}\text { Added value, } \\
\text { thousand rubles }\end{array}$ \\
\hline \multirow[t]{5}{*}{$\mathrm{C} 1$} & 2014 & 3131670 & 1260430 & 67546 & 1535208 & 268486 \\
\hline & 2015 & 6779431 & 2229452 & 132850 & 2908169 & 1508960 \\
\hline & 2016 & 10049532 & 3182534 & 189466 & 4162060 & 2515472 \\
\hline & 2017 & 9310664 & 4154571 & 236129 & 3696109 & 1223855 \\
\hline & 2018 & 7622516 & 3684271 & 188570 & 2194444 & 1555230 \\
\hline \multirow[t]{5}{*}{$\mathrm{C} 2$} & 2014 & 586073 & 258697 & 40343 & 80100 & 206933 \\
\hline & 2015 & 1617894 & 607625 & 62265 & 134162 & 813842 \\
\hline & 2016 & 2216619 & 987126 & 54508 & 201915 & 973070 \\
\hline & 2017 & 1864400 & 1050612 & 45373 & 429038 & 339377 \\
\hline & 2018 & 1693230 & 926123 & 38746 & 169709 & 558653 \\
\hline \multirow[t]{5}{*}{$\mathrm{C} 3$} & 2014 & 3035636 & 2165849 & 43009 & 600049 & 226730 \\
\hline & 2015 & 3367084 & 2208867 & 41700 & 693339 & 423178 \\
\hline & 2016 & 2871342 & 1449179 & 30636 & 297228 & 1094300 \\
\hline & 2017 & 3005655 & 2054743 & 50386 & 143246 & 757281 \\
\hline & 2018 & 2100807 & 1335954 & 34384 & 208544 & 521925 \\
\hline \multirow[t]{5}{*}{$\mathrm{C} 4$} & 2014 & 3944032 & 2332741 & 190921 & 1094936 & 325434 \\
\hline & 2015 & 5988517 & 2480814 & 290143 & 1889219 & 1328341 \\
\hline & 2016 & 7518566 & 3720391 & 389412 & 785677 & 2623086 \\
\hline & 2017 & 8800104 & 4671917 & 341400 & 2885935 & 900852 \\
\hline & 2018 & 8026296 & 4118555 & 211340 & 2583717 & 1112683 \\
\hline \multirow[t]{5}{*}{ C5 } & 2014 & 1253837 & 624558 & 39592 & 168872 & 420815 \\
\hline & 2015 & 2674746 & 957613 & 57972 & 748983 & 910178 \\
\hline & 2016 & 3921818 & 1031060 & 49200 & 1742912 & 1098646 \\
\hline & 2017 & 3688854 & 1476514 & 102351 & 1699253 & 410736 \\
\hline & 2018 & 2086873 & 910413 & 115568 & 645606 & 415286 \\
\hline \multirow[t]{5}{*}{ C6 } & 2014 & 461124 & 214569 & 5923 & 54906 & 185726 \\
\hline & 2015 & 719600 & 360048 & 4691 & 102842 & 252019 \\
\hline & 2016 & 1460109 & 708839 & 4389 & 398436 & 348445 \\
\hline & 2017 & 1128149 & 660073 & 4441 & 336858 & 126776 \\
\hline & 2018 & 590471 & 410494 & 3515 & 39155 & 137306 \\
\hline \multirow[t]{5}{*}{ C7 } & 2014 & 861259 & 564780 & 14642 & 118144 & 163693 \\
\hline & 2015 & 1799371 & 791315 & 17053 & 293855 & 697147 \\
\hline & 2016 & 3161154 & 1285776 & 22573 & 944794 & 908011 \\
\hline & 2017 & 2078000 & 1344315 & 18189 & 219353 & 496143 \\
\hline & 2018 & 1604644 & 855551 & 24201 & 263722 & 461170 \\
\hline \multirow[t]{5}{*}{$\mathrm{C} 8$} & 2014 & 856503 & 410482 & 11826 & 142694 & 291501 \\
\hline & 2015 & 1905633 & 631549 & 7947 & 786806 & 479332 \\
\hline & 2016 & 3546958 & 1023490 & 12714 & 1593416 & 917338 \\
\hline & 2017 & 2519906 & 873820 & 14231 & 1238852 & 393002 \\
\hline & 2018 & 1057212 & 402462 & 7067 & 298040 & 349643 \\
\hline \multirow{5}{*}{$\begin{array}{l}\text { By group of } \\
\text { organizations }\end{array}$} & 2014 & 14130135 & 7832107 & 413802 & 3794909 & 2089317 \\
\hline & 2015 & 24852276 & 10267284 & 614620 & 7557375 & 6412997 \\
\hline & 2016 & 34746098 & 13388395 & 752895 & 10126438 & 10478369 \\
\hline & 2017 & 32395732 & 16286565 & 812501 & 10648645 & 4648022 \\
\hline & 2018 & 24782049 & 12643824 & 623391 & 6402936 & 5111897 \\
\hline
\end{tabular}

In conditions when organizations receive a positive financial result, which is typical for $\mathrm{C} 1-\mathrm{C} 8$ organizations throughout the entire study period, business analysis of the structure of the cost of sales is of particular interest, the intrastructural proportions of which in a certain way characterize the effectiveness of economic activity. In addition, the economic activity of sugar factories is associated with the need to take into account the influence of factors of external, associated, internal business environment [8]. Integration of these parties is one of the features of the business analysis methodology, the key reference point of which, comprehensively characterizing the effectiveness of sugar beet processing, is 
value added business analysis. This indicator links the results of such components of business activities as [9]:

supply (takes into account the effectiveness of the raw material supply of the production process: external factor - the state and level of development of the system of business relations, characterized by quality characteristics and average market prices for beet raw materials);

production (takes into account the effectiveness of the use of beet raw materials, technological equipment and human resources: internal factor - the state and level of development of production potential, characterized by the yield of sugar);

sales (takes into account the mass of sales income: external factor - the state and level of pricing, characterized by average market prices for sugar and by-products).

Let us consider, using a conventional example, the procedure for the formation of added value in the area of interest of the selected stakeholders (owner, staff, state).

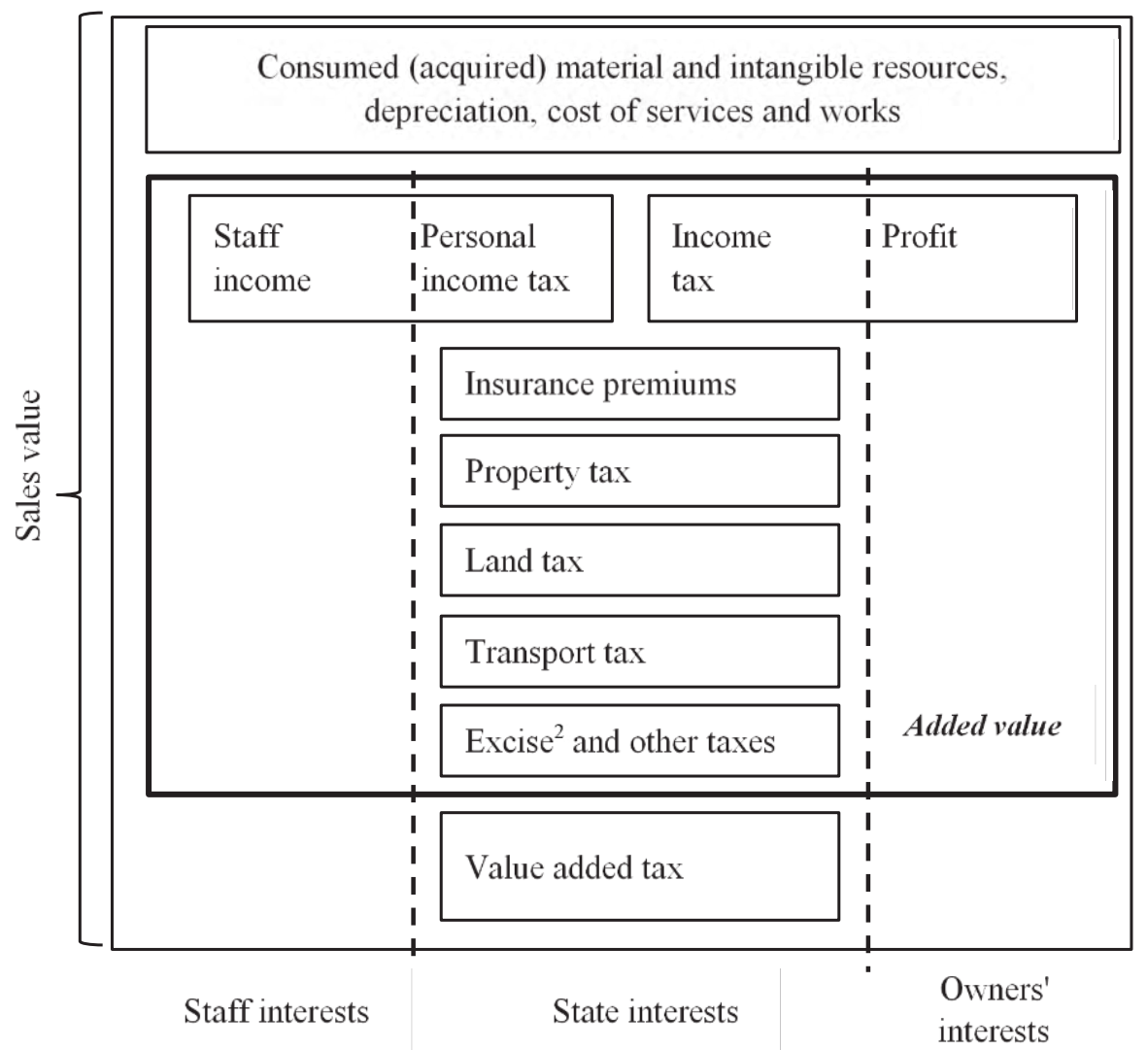

Fig. 1. Structural characteristics of the cost of product sales.

The results obtained indicate that $41.14 \%$ of value added tax is charged on the amounts ultimately paid to the budget in the form of taxes and fees. It should be noted that if the transport tax, land tax, personal income tax, insurance premiums and environmental payments are included in the cost price and, thereby, reduce the taxable base for income tax, then the VAT calculated on these amounts leads to an increase in product prices, not reducing profits.

Thus, the added value and the payments to the budget generated by it act as the main source of satisfaction of the interests of the personnel, owners and the state. In this context, the establishment of parity proportions of the distribution of value added is of priority 
importance. When establishing the specified proportions, it is important to recognize the use of staff salaries, adjusted by the amount of withholding tax on personal income, which makes it possible to judge the real possibilities of meeting the needs of staff. Only after this condition is met, it is possible to assess the dynamic ratio of productivity and wages.

Table 3. Distribution of the added value of $\mathrm{C} 1-\mathrm{C} 8$ sugar production organizations in the Voronezh region by areas of interest of the main stakeholders.

\begin{tabular}{|c|c|c|c|c|c|c|c|}
\hline \multirow{3}{*}{ Organization } & \multirow{3}{*}{ Year } & \multicolumn{2}{|c|}{ Personnel interest area } & \multicolumn{2}{|c|}{ Owners' interests zone } & \multicolumn{2}{|c|}{ State interests zone } \\
\hline & & \multicolumn{2}{|c|}{ Labor costs } & \multicolumn{2}{|c|}{ Net profit } & \multicolumn{2}{|c|}{ Value added taxes and fees } \\
\hline & & $\begin{array}{c}\text { thousand } \\
\text { rubles }\end{array}$ & $\%$ & thousand rubles & $\%$ & $\begin{array}{c}\text { thousand } \\
\text { rubles }\end{array}$ & $\%$ \\
\hline \multirow[t]{5}{*}{$\mathrm{C} 1$} & 2014 & 75724 & 28,20 & 101110 & 37,66 & 91652 & 34,14 \\
\hline & 2015 & 101125 & 6,70 & 1057751 & 70,10 & 350084 & 23,20 \\
\hline & 2016 & 123425 & 4,91 & 1716760 & 68,25 & 675287 & 26,85 \\
\hline & 2017 & 172541 & 14,10 & 590113 & 48,22 & 461201 & 37,68 \\
\hline & 2018 & 205868 & 13,24 & 848852 & 54,58 & 500510 & 32,18 \\
\hline \multirow[t]{5}{*}{$\mathrm{C} 2$} & 2014 & 62449 & 30,18 & 93458 & 45,16 & 51026 & 24,66 \\
\hline & 2015 & 105372 & 12,95 & 483699 & 59,43 & 224771 & 27,62 \\
\hline & 2016 & 102539 & 10,54 & 525036 & 53,96 & 345495 & 35,51 \\
\hline & 2017 & 96296 & 28,37 & 83500 & 24,60 & 159581 & 47,02 \\
\hline & 2018 & 94615 & 16,94 & 296050 & 52,99 & 167988 & 30,07 \\
\hline \multirow[t]{5}{*}{$\mathrm{C} 3$} & 2014 & 103865 & 45,81 & 52273 & 23,06 & 70592 & 31,13 \\
\hline & 2015 & 106213 & 25,10 & 176050 & 41,60 & 140915 & 33,30 \\
\hline & 2016 & 85000 & 7,77 & 703094 & 64,25 & 306206 & 27,98 \\
\hline & 2017 & 150615 & 19,89 & 328504 & 43,38 & 278162 & 36,73 \\
\hline & 2018 & 104761 & 20,07 & 370151 & 70,92 & 47013 & 9,01 \\
\hline \multirow[t]{5}{*}{$\mathrm{C} 4$} & 2014 & 123627 & 37,99 & 106754 & 32,80 & 95053 & 29,21 \\
\hline & 2015 & 109273 & 8,23 & 895056 & 67,38 & 324012 & 24,39 \\
\hline & 2016 & 136961 & 5,22 & 1785559 & 68,07 & 700566 & 26,71 \\
\hline & 2017 & 190857 & 21,19 & 303300 & 33,67 & 406695 & 45,15 \\
\hline & 2018 & 185828 & 16,70 & 513549 & 46,15 & 413306 & 37,14 \\
\hline \multirow[t]{5}{*}{$\mathrm{C} 5$} & 2014 & 56664 & 13,47 & 75304 & 17,89 & 288847 & 68,64 \\
\hline & 2015 & 77114 & 8,47 & 388861 & 42,72 & 444203 & 48,80 \\
\hline & 2016 & 58730 & 5,35 & 567233 & 51,63 & 472683 & 43,02 \\
\hline & 2017 & 85805 & 20,89 & 8656 & 2,11 & 316275 & 77,00 \\
\hline & 2018 & 56777 & 13,67 & 6786 & 1,63 & 351723 & 84,69 \\
\hline \multirow[t]{5}{*}{ C6 } & 2014 & 45308 & 24,40 & 46339 & 24,95 & 94079 & 50,65 \\
\hline & 2015 & 42634 & 16,92 & 90309 & 35,83 & 119076 & 47,25 \\
\hline & 2016 & 50859 & 14,60 & 190586 & 54,70 & 107000 & 30,71 \\
\hline & 2017 & 55416 & 43,71 & 1895 & 1,49 & 69465 & 54,79 \\
\hline & 2018 & 43933 & 32,00 & 47553 & 34,63 & 45820 & 33,37 \\
\hline \multirow[t]{5}{*}{ C7 } & 2014 & 70004 & 42,77 & 49173 & 30,04 & 44516 & 27,19 \\
\hline & 2015 & 70327 & 10,09 & 429350 & 61,59 & 197470 & 28,33 \\
\hline & 2016 & 87170 & 9,60 & 602403 & 66,34 & 218438 & 24,06 \\
\hline & 2017 & 78470 & 15,82 & 241164 & 48,61 & 176509 & 35,58 \\
\hline & 2018 & 62201 & 13,49 & 301407 & 65,36 & 97562 & 21,16 \\
\hline \multirow[t]{5}{*}{$\mathrm{C} 8$} & 2014 & 40852 & 14,01 & 53214 & 18,26 & 197435 & 67,73 \\
\hline & 2015 & 36948 & 7,71 & 278541 & 58,11 & 163843 & 34,18 \\
\hline & 2016 & 56084 & 6,11 & 487290 & 53,12 & 373964 & 40,77 \\
\hline & 2017 & 59930 & 15,25 & 75397 & 19,18 & 257675 & 65,57 \\
\hline & 2018 & 32211 & 9,21 & 127673 & 36,52 & 189759 & 54,27 \\
\hline \multirow{5}{*}{$\begin{array}{c}\text { By group of } \\
\text { organizations }\end{array}$} & 2014 & 578492 & 27,69 & 577625 & 27,65 & 933200 & 44,67 \\
\hline & 2015 & 649006 & 10,12 & 3799617 & 59,25 & 1964374 & 30,63 \\
\hline & 2016 & 700769 & 6,69 & 6577961 & 62,78 & 3199639 & 30,54 \\
\hline & 2017 & 889930 & 19,15 & 1632529 & 35,12 & 2125563 & 45,73 \\
\hline & 2018 & 786195 & 15,38 & 2512021 & 49,14 & 1813681 & 35,48 \\
\hline
\end{tabular}


The actual data indicate the absence of any proportions in the distribution of the value added of the surveyed organizations (Table 3). The smallest share of value added is distributed in the form of wages (87.5\% of all observations), an increase in the level of this indicator was observed only in cases where the organization received a relatively small amount of profit (for most organizations in 2014). The results obtained indicate that, despite a certain increase in average annual wages, its level does not depend on the mass of value added.

Certain imbalances were caused by changes, primarily in the area of interests of the owners of the organization:

significant amounts of "input VAT" accepted for offset;

participation of factories (in terms of modernization programs) in particularly significant regional projects. As a result, the initial cost of fixed assets in each of their organizations $\mathrm{C} 1, \mathrm{C} 4$ and $\mathrm{C} 5$ increased by more than 1.5 billion rubles in five years. In accordance with the legislation of the Voronezh region, organizations were provided with benefits for income tax;

receiving significant net profit in 2015-2016. In 2016, the organizations produced the maximum volume of beet sugar 590.82 thousand tons, which, against the background of the high price level for white granulated sugar, provided the formation of a significant amount of profit from sales -6.5 billion rubles and net profit - 6.6 billion rubles. In 2015 and 2016, five and seven sugar factories, respectively, were included in the top 25 organizations of the Voronezh region in terms of net profit. The net profit received by the sugar factories was $6.15 \%$ (2015) and $11.35 \%$ (2016) across the region.

For processing organizations, net profit is the main source of replenishment of equity capital and the satisfaction of the target financial interests of their owners. Sugar factories of the Voronezh region do not practice the annual calculation and payment of dividends. According to the financial statements of organizations in 2012-2013, dividends, despite positive financial results, were not accrued. In addition, the situation that developed in the organization C3 in 2015 is interesting: dividends were paid by 181.237 million rubles more than accrued. At the same time, there were no accounts payable to the founders for previous periods in the $\mathrm{C} 3$ organization, and the total amount of paid dividends was 2.74 times higher than the organization's net profit at the end of 2015. In general, for the period 20152016, the group of the studied sugar production organizations in the Voronezh region paid dividends for 3.2 billion rubles. (31.67\% of net profit for 2015-2016).

The use of the cost approach in assessing labor productivity has a number of limitations, some of which were discussed by us above. One of the possible options for the valuation of labor productivity is to determine the hypothetical mass of income from the sale of all manufactured products for the reporting year at average prices for this period. However, when using this approach, there will be no relationship with the actually generated mass of value added. Therefore, to reveal the structural links and assess the proportions of the actual distribution of value added, the following indicators were adjusted: material costs, depreciation, and subsequently personal income tax when calculating dynamic ratios. In addition, in accordance with the position we justified above, for the purposes of conducting a process-cost business analysis, the mass of value added for calculating labor productivity was increased by the amount of VAT payable to the budget (Table 4).

The best in terms of labor productivity for all surveyed organizations without exception was 2016, the worst (in most cases) - 2014. The data obtained also indicate the presence of a linear dependence of the production results on the provision of high-quality beet raw materials. Thus, this aspect should be recognized as another limitation of labor productivity for organizations of sugar production, which, as a rule, is due to the influence of natural and climatic conditions and is characteristic of organizations that process raw materials of agricultural origin. In such conditions of the negative manifestation of the impact of 
external and associated environment factors, the choice of a shorter assessment period, for example, 9 months, can be considered correct. At the same time, the analytical results obtained in a similar way, in our opinion, cannot be used for comparison with the average annual values of the indicators of the same name.

Table 4. Assessment of labor productivity in organizations C1 - C8 of the Voronezh region (2014 2018).

\begin{tabular}{|c|c|c|c|c|c|c|}
\hline Organization & Year & $\begin{array}{l}\text { Value added } \\
\text { (VA), thousand } \\
\text { rubles }\end{array}$ & $\begin{array}{l}\text { VAT payable to } \\
\text { the budget, } \\
\text { thousand rubles }\end{array}$ & \begin{tabular}{|c|} 
The amount of \\
VA and VAT \\
payable, thousand \\
rubles.
\end{tabular} & $\begin{array}{l}\text { Average annual } \\
\text { number of } \\
\text { personnel, people }\end{array}$ & \begin{tabular}{|c} 
Labor \\
productivity, \\
thousand rubles \\
/ person \\
\end{tabular} \\
\hline 1 & 2 & 3 & 4 & $5=3+4$ & 6 & $7=5 / 6$ \\
\hline \multirow[t]{5}{*}{$\mathrm{C} 1$} & 2014 & 268486 & -72965 & 268486 & 465 & 577 \\
\hline & 2015 & 1508960 & -54670 & 1508960 & 513 & 2941 \\
\hline & 2016 & 2515472 & 146818 & 2662290 & 518 & 5140 \\
\hline & 2017 & 1223855 & 147743 & 1371598 & 565 & 2428 \\
\hline & 2018 & 1555230 & 148563 & 1703793 & 639 & 2666 \\
\hline \multirow[t]{5}{*}{$\mathrm{C} 2$} & 2014 & 206933 & -4191 & 206933 & 339 & 610 \\
\hline & 2015 & 813842 & 64810 & 878652 & 345 & 2547 \\
\hline & 2016 & 973070 & 158444 & 1131514 & 370 & 3058 \\
\hline & 2017 & 339377 & 66387 & 405764 & 358 & 1133 \\
\hline & 2018 & 558653 & 62262 & 620915 & 329 & 1887 \\
\hline \multirow[t]{5}{*}{$\mathrm{C} 3$} & 2014 & 226730 & -10843 & 226730 & 476 & 476 \\
\hline & 2015 & 423178 & 5960 & 429138 & 476 & 902 \\
\hline & 2016 & 1094300 & 65981 & 1160281 & 382 & 3037 \\
\hline & 2017 & 757281 & 97689 & 854970 & 370 & 2311 \\
\hline & 2018 & 521925 & 69083 & 591008 & 382 & 1547 \\
\hline \multirow[t]{5}{*}{$\mathrm{C} 4$} & 2014 & 325434 & 0 & 325434 & 526 & 619 \\
\hline & 2015 & 1328341 & 0 & 1328341 & 558 & 2381 \\
\hline & 2016 & 2623086 & 136302 & 2759388 & 590 & 4677 \\
\hline & 2017 & 900852 & 147625 & 1048477 & 662 & 1584 \\
\hline & 2018 & 1112683 & 70496 & 1183179 & 607 & 1949 \\
\hline \multirow[t]{5}{*}{$\mathrm{C} 5$} & 2014 & 420815 & 233240 & 654055 & 271 & 2413 \\
\hline & 2015 & 910178 & 307268 & 1217446 & 270 & 4509 \\
\hline & 2016 & 1098646 & 292070 & 1390716 & 276 & 5039 \\
\hline & 2017 & 410736 & 240261 & 650997 & 281 & 2317 \\
\hline & 2018 & 415286 & 252823 & 668109 & 296 & 2257 \\
\hline \multirow[t]{5}{*}{ C6 } & 2014 & 185726 & 61282 & 247008 & 221 & 1118 \\
\hline & 2015 & 252019 & 79041 & 331060 & 238 & 1391 \\
\hline & 2016 & 348445 & 28439 & 376884 & 249 & 1514 \\
\hline & 2017 & 126776 & 33306 & 160082 & 236 & 678 \\
\hline & 2018 & 137306 & 4766 & 142072 & 227 & 626 \\
\hline \multirow[t]{5}{*}{$\mathrm{C7}$} & 2014 & 163693 & -20156 & 163693 & 222 & 737 \\
\hline & 2015 & 697147 & 64663 & 761810 & 228 & 3341 \\
\hline & 2016 & 908011 & 22849 & 930860 & 244 & 3815 \\
\hline & 2017 & 496143 & 77327 & 573470 & 250 & 2294 \\
\hline & 2018 & 461170 & -69832 & 461170 & 254 & 1816 \\
\hline \multirow[t]{5}{*}{$\mathrm{C} 8$} & 2014 & 291501 & 127669 & 419170 & 285 & 1471 \\
\hline & 2015 & 479332 & 49996 & 529328 & 294 & 1800 \\
\hline & 2016 & 917338 & 187592 & 1104930 & 285 & 3877 \\
\hline & 2017 & 393002 & 163622 & 556624 & 283 & 1967 \\
\hline & 2018 & 349643 & 165436 & 515079 & 264 & 1951 \\
\hline \multirow{5}{*}{$\begin{array}{l}\text { By group of } \\
\text { organizations }\end{array}$} & 2014 & 2089317 & 314036 & 2403353 & 2805 & 857 \\
\hline & 2015 & 6412997 & 517068 & 6930065 & 2922 & 2372 \\
\hline & 2016 & 10478369 & 1038495 & 11516864 & 2914 & 3952 \\
\hline & 2017 & 4648022 & 973960 & 5621982 & 3005 & 1871 \\
\hline & 2018 & 5111897 & 703597 & 5815494 & 2998 & 1940 \\
\hline
\end{tabular}


Table 5. Dynamic ratio of productivity and wages in organizations C1 - C8 of the Voronezh region (2014 - 2018).

\begin{tabular}{|c|c|c|c|c|}
\hline Organization & Year & $\begin{array}{l}\text { The rate of dynamics of the } \\
\text { average annual wage per } \\
\text { employee, } \%\end{array}$ & $\begin{array}{l}\text { Labor productivity } \\
\text { dynamics, } \%\end{array}$ & Lead coefficient, units \\
\hline 1 & 2 & 3 & 4 & $5=4 / 3$ \\
\hline \multirow{4}{*}{$\mathrm{C} 1$} & 2015 & 121,05 & 509,44 & 4,21 \\
\hline & 2016 & 120,87 & 174,73 & 1,45 \\
\hline & 2017 & 128,17 & 47,23 & 0,37 \\
\hline & 2018 & 105,50 & 109,83 & 1,04 \\
\hline \multirow{4}{*}{$\mathrm{C} 2$} & 2015 & 165,80 & 417,22 & 2,52 \\
\hline & 2016 & 90,74 & 120,08 & 1,32 \\
\hline & 2017 & 97,06 & 37,06 & 0,38 \\
\hline & 2018 & 106,91 & 166,51 & 1,56 \\
\hline \multirow{4}{*}{$\mathrm{C} 3$} & 2015 & 102,26 & 189,27 & 1,85 \\
\hline & 2016 & 99,72 & 336,91 & 3,38 \\
\hline & 2017 & 182,94 & 76,08 & 0,42 \\
\hline & 2018 & 67,37 & 66,95 & 0,99 \\
\hline \multirow{4}{*}{$\mathrm{C} 4$} & 2015 & 83,32 & 384,77 & 4,62 \\
\hline & 2016 & 118,54 & 196,47 & 1,66 \\
\hline & 2017 & 124,20 & 33,86 & 0,27 \\
\hline & 2018 & 106,19 & 123,07 & 1,16 \\
\hline \multirow{4}{*}{$\mathrm{C} 5$} & 2015 & 136,59 & 186,83 & 1,37 \\
\hline & 2016 & 74,50 & 111,75 & 1,50 \\
\hline & 2017 & 143,50 & 45,98 & 0,32 \\
\hline & 2018 & 62,82 & 97,43 & 1,55 \\
\hline \multirow{4}{*}{$\mathrm{C} 6$} & 2015 & 87,38 & 124,45 & 1,42 \\
\hline & 2016 & 114,02 & 108,81 & 0,95 \\
\hline & 2017 & 114,96 & 44,81 & 0,39 \\
\hline & 2018 & 82,42 & 92,27 & 1,12 \\
\hline \multirow{4}{*}{$\mathrm{C} 7$} & 2015 & 97,82 & 453,14 & 4,63 \\
\hline & 2016 & 115,82 & 114,18 & 0,99 \\
\hline & 2017 & 87,86 & 60,13 & 0,68 \\
\hline & 2018 & 78,02 & 79,15 & 1,01 \\
\hline \multirow[b]{4}{*}{ C8 } & 2015 & 87,67 & 122,41 & 1,40 \\
\hline & 2016 & 156,59 & 215,33 & 1,38 \\
\hline & 2017 & 107,61 & 50,73 & 0,47 \\
\hline & 2018 & 57,62 & 99,20 & 1,72 \\
\hline \multirow{4}{*}{$\begin{array}{l}\text { By group of } \\
\text { organizations }\end{array}$} & 2015 & 107,70 & 276,80 & 2,57 \\
\hline & 2016 & 108,27 & 166,64 & 1,54 \\
\hline & 2017 & 123,15 & 47,34 & 0,38 \\
\hline & 2018 & 88,55 & 103,68 & 1,17 \\
\hline
\end{tabular}

The values of the advance coefficient characterizing the ratio of the rates of dynamics of labor productivity and rates of dynamics of wages were less than one in 11 out of 40 observations, which does not correspond to the generally accepted level (1.0 units), ensuring the development of the organization (Table 5). First, organizations annually received a sufficient amount of net profit, which made it possible to modernize production facilities, pay a significant amount of dividends, and significantly reduce borrowed sources of financing - all this indicates the development of the organization. Secondly, in the surveyed organizations, the increase in labor productivity was mainly due to three main factors for sugar production: an increase in production capacity, an increase in prices for finished products, high yields of beet raw materials and an increase in its quality characteristics, against which the impact of the quality of personnel labor on the volume of products produced is not significant. Thirdly, empirical data made it possible to identify a trend characteristic of all organizations - the cyclical growth of labor productivity due to the influence of raw materials and technical components. Thus, in the current situation, the use 
of criterion values of the advance coefficient as a tool for assessing the possibilities and directions of development of sugar factories in the Voronezh region is not advisable.

\section{Discussion}

The majority of agro-industrial complex processing organizations are characterized by the presence of factors and processes identified in the course of a survey of sugar production organizations in the Voronezh region. In particular, an unreasonably low level of assessment of the work of employees of Russian organizations is noted in the works of Kositsina,. Nigmatulin, Bakhtizin, Sulakshina, Pirogovoy., Nuzhdina and others $[10,11,12]$. We share the position of the authors who consider it necessary to increase the size of wages in domestic processing organizations, regardless of the level of labor productivity. At the same time, a feature of traditional material-intensive industries, which include sugar beet processing, is the absence of a high correlation between wages and the volume of products produced, as well as the negative (in terms of assessing labor productivity and staff motivation) influence of the time factor. In this regard, the management of processing organizations use the increase in wages to retain the most valuable, as a rule, management personnel. In other cases, the increase in wages is a reaction to inflationary processes or other changes in the external, not internal environment. In addition, previous studies [13] indicate that, despite the high level of profitability of the economic activity of sugar factories in the Voronezh region, the average level of remuneration of their personnel in certain periods was lower than the average for the region.

The main parametric characteristics that need to be paid close attention are the following indicators: the share of value added in total income and the share of wages in value added [14]. As a rule, the economic activity of agribusiness entities does not generate high benefit. However, as the results showed, its share in the income of the surveyed organizations varied on average for the group in the range from $14 \%$ to $30 \%$, with the determining factor being the level of prices for finished products.

The distribution of added value between staff, owners, and the state is carried out in the surveyed organizations without observing any proportions, which, given the insufficient level of remuneration, contributes to an increase in disparity in meeting the interests of stakeholders, primarily personnel. Drawing a certain analogy between the value added of an economic entity and GDP on a national scale, one can make an assumption about the need to ensure a comparable level of labor costs in their structure. The share of labor costs in GDP is approximately 25\% [15], the share of value added on average for the group of surveyed organizations for 2014-2018 was $15.81 \%$, which should be recognized as an unreasonably low value even in comparison with the structure of GDP. It is permissible to use the level of 50-55\% [15] recommended by individual authors for GDP as a target for labor costs at the level of organizations, which, in our opinion, will significantly increase staff motivation, the welfare of the population and the competitiveness of the domestic economy.

The positive ratio of the dynamics of labor productivity and labor costs in the surveyed organizations is due not to an increase in the quality and results of labor, but to the influence of price factors, the development of the material and technical base and favorable weather conditions. The significant dependence of the results of the economic activity of sugar factories on the volume and quality of beet raw materials contributed to the development of Prodimex Group of its own raw material bases and the use of highly productive hybrids of foreign selection. Thus, there is a high efficiency of the management decisions taken aimed at achieving strategic goals and increasing the competitiveness of organizations, against the background of palliative measures for the development of production personnel. 


\section{Conclusion}

Consideration of labor results in the context of process-cost business analysis made it possible to substantiate the need to analyze the level, dynamics and proportions of the distribution of value added between personnel, owners and the state. A certain scientific value and practical significance have been put forward and tested recommendations for calculating the mass of value added for assessing labor productivity:

1)take into account when calculating the mass of income and expenses from other types of activities. In the organizations of sugar production C1, C5 and C8 in 2016-2017, the masses of income for the main and other types of activities varied at a comparable level and, as a result, had an equal impact on the assessment results.;

2)stop using gross value added in valuation procedures. Use net value added, adjusted by the amount of accrued depreciation, which should be perceived as a result of the activities of partner organizations;

3)neutralize the influence of the time factor, which manifests itself in the mismatch of the periods of production and sale of finished products. For this, it is proposed to adjust the amount of material costs (and equivalent costs) and depreciation, taking into account balances, volumes of manufactured and shipped products. In the surveyed organizations, a trend was revealed for an increase in the shelf life of products, which is caused, on the one hand, by the overproduction of sugar in the country, and on the other hand, by the use of opportunities for obtaining a greater mass of income in the face of rising market prices.;

4)when assessing the parity of the distribution of value added between stakeholders, transfer the amounts of personal income tax withheld from the area of personnel interests to the area of interests of the state, and also take into account, in addition, in the area of responsibility of the state, the amounts of VAT payable to the budget. The priority from the standpoint of ensuring the parity of interests of the main stakeholders is, first, an increase in the share of expenses for personnel remuneration and the implementation of existing opportunities to increase the share of value added in the total revenues of the organization.

In the course of the study, it was concluded that it is inexpedient to use any numerical values as evaluative criteria when analyzing the dynamic ratio of productivity and wages, since at present the prevailing influence on the background of unjustified low remuneration of personnel on the results of their activities is: the development of the technical component of economic activity, provision of quality raw materials of agricultural origin, the level of prices for finished products. The considered methodological approach is an effective tool, the use of which in the process of business analysis and forecasting makes it possible to determine not only the possible level of added value and its individual elements, but also the level of labor productivity and achieving the interests of the main stakeholders.

\section{References}

1. R.V. Nuzhdin, E.V. Endovitskaya, Assessment of the raw and labor components of sugar beet production: methodological justification, Sugar. 11, 50-54 (2018)

2. A.M. Matyagina, E.V. Smirnova, Environmentally responsible business, Moscow: FORUM (2011)

3. K.P. Kolotyrin, Economic instruments for stimulating environmental activities, Bulletin of the Saratov State Technical University 1 (37), 186-196 (2009)

4. S.N. Bobylev, A.Sh. Khodjaev, Environmental Economics (Textbook Moscow: INFRA-M. 2007) 
5. A.A. Abdalhussein, M.S. Santalova, Human potential and human capital in the production activity of an enterprise, Social and economic phenomena and processes 6 (052) (2013)

6. S.V. Nenasheva Human capital: essence and structure, Izvestiya OSAU 4, 36-1, 151 - 153 (2012)

7. L. Thurow, Investment in Human Capital, Belmont (1970)

8. E.G. Flamholtz, Human Resource Accounting, N. Y.: Jossey-Bass Publ. (1985)

9. A. Sen, Development as Freedom, New Publishing (2004)

10. T. Schultz, Investment in Human Capital, Economic Growth - an American Problem. Englewood Cliffs (1964)

11. J. Fitzenz, Return on investment in staff (2006)

12. L. Prusak, How to turn knowledge into value: Solutions from the IBM Institute for Business Value (Alpina Business Books, 248, 2006)

13. D.A. Kiryanov, Methods of human capital assessment: analysis of objectivity and sufficiency of initial data, Theory and practice of social development 3 (2012)

14. O.E. Pirogova, The approach to assessing the intellectual capital of a commercial enterprise within the framework of the VBM concept, News of St. Petersburg State University of Economics 2 (116), 102-109 (2019)

15. V. Plotnikov, O. Pirogova, Key Competencies as an Enterprise Value Management Tool, Proceedings of the 31st International Business Information Management Association Conference (IBIMA) «Innovation Management and Education Excellence through Vision», 25-26 April. Milan, Italy (2018) 